\section{ECONOMICS}

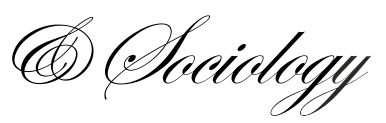

Habánik, J., Grenčíková, A., Šrámka, M., \& Húževka, M. (2021). Changes in the organization of work under the influence of COVID-19 pandemic and Industry 4.0. Economics and Sociology, 14(4), 228-241. doi:10.14254/2071-789X.2021/14$4 / 13$

\title{
CHANGES IN THE ORGANIZATION OF WORK UNDER THE INFLUENCE OF COVID-19 PANDEMIC AND INDUSTRY 4.0
}

\author{
Jozef Habánik \\ Faculty of Social and Economic \\ Relations \\ Alexander Dubcek University in \\ Trencin, Slovakia \\ E-mail: jozef.habanik.@,tnuni.sk. \\ ORCID 0000-0001-7898-2735
}

\author{
Adriana Grenčíková \\ Faculty of Social and Economic \\ Relations \\ Alexander Dubcek University in \\ Trencin, Slovakia \\ E-mail: \\ adriana.grencikova@tnuni.sk. \\ ORCID 0000-0003-1077-1127
}

\section{Martin Šrámka \\ Faculty of Social and Economic \\ Relations \\ Alexander Dubcek University in \\ Trencin, Slovakia \\ E-mail:martin.sramka@,tnuni.sk \\ ORCID 0000-0001-7229-3015 \\ Matej Húževka \\ Faculty of Social and Economic \\ Relations \\ Alexander Dubcek University in \\ Trencin, Slovakia \\ E-mail:matej.buzevka@,tnuni.sk. ORCID 0000-0003-0137-4656}

Received: November, 2020

1st Revision: September, 2021

Accepted: December, 2021

DOI: $10.14254 / 2071-$

789X.2021/14-4/13

JEL Classification: F66, J24, O31, O33, Q55

\begin{abstract}
The COVID-19 pandemic deeply affects all spheres of public life across countries and regions not only in social, ethical, political and psychological context, but also in economy. The unprecedented circumstances have disturbed the existing processes and activities in the whole society and markedly altered the functioning of the labour market and the behaviour of its actors. Significant government interventions in the labour market have been justified by the introduction of restrictive quarantine measures, which affect the usual procedures. Employers as well as employees have therefore been forced to face new challenges, to which they must adapt flexibly to survive in the labour market. Professional training has also been affected as it has been carried out in virtual space for almost a year. For the time being, we can only suppose the effects on knowledge and skills of the future workforce. In addition to the negative effects, the pandemic has brought opportunities, new challenges, and space for the optimization of human resources which are becoming critically important, especially in production organizations. The use of information and communication technologies has broadened due to the introduction of the smart industry concept, which has a direct impact on the labour market, in particular on changes in labour demand. The requirements for the skills and knowledge of the workforce are changing, as is the way the work is organized. As part of two questionnaire surveys four months apart, we analysed the impact of the introduction of a home office on labour productivity, employee satisfaction as well as social isolation of individuals. The sample size of the first pilot survey was 302 respondents, the second one - 284. We subsequently processed and evaluated the acquired data using a range of statistical methods, reporting only selected results of the surveys in the present study.
\end{abstract}

Keywords: pandemic covid-19, work organization, home-office, information-communication technologies, human capital 


\section{Introduction}

In modern history, it is difficult to identify a time comparable to the present situation. Nevertheless, history does offer examples of pandemics changing the course of world events (including the structure of the labour market) - and according to several experts, the current crisis will have similar lasting consequences (Saadat, Rawtani, Hussain, 2020). There is a tendency to draw analogies between the current circumstances and the situation more than a century ago, when the world experienced a global Spanish influenza pandemic. However, the truth is that any objective comparison of the effects of these crises is not practical. Compared to the past, the labour market of the $21^{\text {st }}$ century is defined by globalization and ever-increasing international interdependence; it is an incomparably more complex mechanism and a more dynamic institution, which naturally determines its resilience to influences of various kinds. The dynamics of the pandemic has permeated and altered virtually all facets of society. As social and economic processes interact with each other, close cooperation among all relevant actors is a key to containing COVID-19 and mitigating its economic repercussions on nations around the globe (Morgan, Awafo, Quartey, 2021). A year has passed since the World Health Organization declared COVID-19 a pandemic. No matter whether we consider the economic hardship to be the direct effects of the pandemic or the effects of severe restrictions enforced on national or international levels, without doubt, the COVID-19 pandemic has all the characteristics of a crisis with its economic, social and psychological ramifications. The labour market is a place where employers and workers interact with one another. It is the collaboration among nations that is a key to progress, economic growth and decent standard of living. One of the measures to mitigate the spread of COVID-19 is to minimize the amount of close contact with other people. It is, however, true that severe restrictions on cross-border movement disrupt market supply; they bring about higher unemployment and slower economic growth (Leduc, Liu, 2020). This is the case of Slovakia, too. Since March 2020, a number of restrictive measures have been adopted at both the EU and national level with varying intensity of impact on public and private sectors. Like in other countries, the restrictive measures were to limit human mobility. In order to survive, businesses had to embrace digital tools and technologies that are deemed critical in terms of work performance when working from home (Baruch et al., 1997, Mallett et al., 2020). We have been observing an unprecedented increased use of information and communication technologies, flexible forms of employment, smart virtual platforms, etc. These trends have impacted both businesses and workers. It can be said that the COVID-19 pandemic is putting the flexibility of the labour market to the test. Remote work should not be used only in crisis; it should be standard practice (Davidescu, Apustu, Paul, Casuneanu, 2020). Recent changes in the labour market have prompted process optimisation and higher work efficiency in many businesses. Last but not least, they have dramatically accelerated the use of information and communication technologies and the development of new applications and communication systems. The aim of the present study is to analyze the relationship between these influences on the way work is organized and the effects on individual employees. The paper is structured as follows. After the introduction, the literature review section presents the views and opinions of several authors on the topics related to this study. Paper continues with used methodology, followed by the results of the pilot survey and the final conclusion. 


\section{Literature review}

Societies around the world are experiencing profound transformations of all kinds. Concerning economy, Belás et al. (2020) claim that companies are facing serious challenges that are connected with competitiveness due to the present economic situation. Mura (2020) point out that generally the business environment is extremely challenging what was underlined also by covid pandemic and crisis situation. The economies of the countries are more focused on the processes related to innovations and applied research as well as on other long-term factors of economic and social development for the past years. The companies need to increase their competitiveness by implementing progressive technologies. The outbreak of the COVID-19 pandemic has plunged the whole world, society and economy down. According to Zhang (2021) the history is showing us a similar phenomenon of Spanish flu of 1918; other recent examples include the Ebola outbreak in 2019, the Ebola hemorrhagic fever in 2014, the H1N1 influenza virus in 2009, the 2005-2016 Zika fever, and SARS in 2003. When looking at what's going on across the world now, it seems that society has not yet learned the lessons from history and from what has happened during the current pandemic.

On the one hand, the pandemic has led to recession, higher unemployment rates and lower household incomes. On the other hand, the pandemic has accelerated the implementation and usage of information and communication technology, which changes the skills and competences that workers should have. Bilan et al. (2019) maintain that nowadays, the impact of ICT factors on the development of economic and economically driven processes is indisputable. Being one of the rapid economic progress drivers, ICT, especially their IT segment, have both advantages and disadvantages, which only proves their importance and the need to take them into account in economic relations on different levels. The concept of Industry 4.0 encompasses ICT, digital transformation of manufacturing, big data, Cloud Computing, Internet of Things, and cyber-physical systems. Industry 4.0 has positive effects on the economy; in particular, it leads to improvements in the processing of information, its distribution among the participants and accessibility. As stated by Matijová (2019) also such an area as tourism is influenced by information technology. Lampropoulos, Siakas and Anastasiadis (2019) presented the Industry 4.0 which enables physical assets to be integrated into intertwined digital and physical processes thus creating smart factories and intelligent manufacturing environments. New intellectual capabilities provide the opportunity to receive actual and reliable information in real time, reduce the time to process data, sorting and classifying information, increasing its quality and relevance for quick and up-to-date decisions (Min et al., 2018). Innovations play a major role in implementing information and communication technologies and Industry 4.0. Formánek and Krajčík (2017) claim that innovation is understood mainly as a function of creativity, idea, opportunity, courage, determination, and innovation implementation. Müller et al. (2018) and Krajňáková et al. (2017) maintain that today's fast development of communication technologies is accelerating the globalization of society at an increasing pace. According to Belás el.al. (2020) the critical attention paid to the use if information communication technology can improves the managerial processes and practices in SME's management.

COVID-19 pandemic speeded up the implementation of Industry 4.0 technology. Globally, employers had to respond to the coronavirus outbreak to protect their employees. In order to contain the spread of the COVID-19 virus and keep workers safe, many employers introduced remote work. This type of flexible work practices has been extensively studied by many scholars.

Kniffin et al. (2020) and Wang (2021) observe that because of this situation, prior to COVID-19, most workers had little remote working experience; nor were they or their organizations prepared for supporting this practice. Now, the unprecedented outbreak of the 
COVID-19 pandemic in 2020 has required millions of people across the world into being remote workers, inadvertently leading to a de facto global experiment of remote working. COVID-19 caused an acceleration of trends that were already underway involving the migration of work to online or virtual environments. Thus, this pandemic has suddenly changed how people work and it is not yet very clear how long we have to continue working from home in different countries (Contreras et al., 2020). Scientific literature is illustrating some positives and negatives aspects of working from home. According to Dobrosotskiy et al. (2019), Ustaev et al. (2018) and Allen et al. (2015) this kind of remote work has some benefits such as better time flexibility, job satisfaction, costs saves and time saves being spent on transport to work and from work. Toscano and Zappalà (2020) state that nevertheless, remote working has been observed to also accomplish negative results, such as professional and social isolation, reduced possibility of being promoted, breakdown of professional relationships, as well as an increase of family-work conflicts.

\section{Methodological approach}

Businesses across Slovakia have been negatively affected by the pandemic due to lockdowns and other restrictions which are often chaotic and make no sense. Whether it is the government measures or consequences of the pandemic, the situation is challenging for both businesses and labour force. The purpose of the study is to analyse the impact of the COVID19 pandemic on employees and the implementation of new ways of working. The first questionnaire survey was conducted in the months of September and October 2020. It was the time when the first wave came to an end and the second wave started in the Slovak Republic. The title of the questionnaire was ,Impacts of the COVID-19 pandemic on employees with a special focus on distant working". The sample consisted of 302 respondents across all the Slovak regions and in different age groups. The second survey was done four months later, in January and February 2021 which is, as the authors believe, sufficient time span for respondents to be able to assess the consequences of the second wave of pandemic in Slovakia. The title of the questionnaire was „Impacts of the second wave of the COVID-19 pandemic on employees with a special focus on distant working". 284 respondents took part in the second survey. The surveys addressed the impacts of the pandemic on employees and businesses, changes in the organization of work, and marked increase of ICTs in remote work. Sample size of both surveys is reflecting the pilot survey requirements. Based on the findings future deeper research could be realized.

The socio-demographic variables used in the surveys were sex, age, background, and the size of the enterprise they work for. The following enterprise size classification was used:

small businesses ( $\leq 49$ employees, incl. microenterprises);

mid-sized businesses (50 to 249 persons employed);

large businesses ( $\geq 250$ persons employed).

To prevent and reduce the spread of COVID-19, the data were collected through an online questionnaire which are available in Slovak version on following links:

- https://www.survio.com/survey/d/N6C8X8P9M1A8L4B9U (first questionnaire)

- https://www.survio.com/survey/d/X0E9J6F2E2A5T2F3O (second questionnaire)

The acquired data were subsequently processed and evaluated with a range of statistical methods and the findings are presented in this study. 


\section{Research and results}

In this section, the outcomes from the 2021 survey are presented. When relevant, they are compared with the 2020 data. Table 1 provides comparative data on the number of respondents, sex, and the size of enterprise they work for.

Table 1. Survey respondents - comparison of basic parameters (September - October 2020 survey, January - February 2021 survey)

\begin{tabular}{|c|c|c|c|}
\hline period & key & total number & share in $\%$ \\
\hline \multirow{11}{*}{ 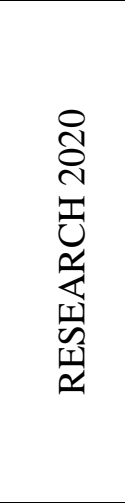 } & number of respondents & 302 & 100 \\
\hline & woman & 180 & 59.6 \\
\hline & men & 122 & 40.4 \\
\hline & from small companies & 104 & 34.4 \\
\hline & from medium-sized companies & 108 & 35.8 \\
\hline & from large companies & 90 & 29.8 \\
\hline & in age $18-25$ years & 82 & 27.2 \\
\hline & in age $26-35$ years & 90 & 29.8 \\
\hline & in age $36-45$ years & 54 & 17.9 \\
\hline & in age $46-55$ years & 54 & 17.9 \\
\hline & in age $56-65$ years & 20 & 6.6 \\
\hline \multirow{11}{*}{ 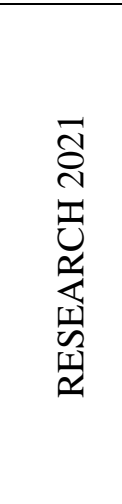 } & number of respondents & 284 & 100 \\
\hline & woman & 178 & 62.7 \\
\hline & men & 106 & 37.3 \\
\hline & from small companies & 98 & 34.5 \\
\hline & from medium-sized companies & 90 & 31.7 \\
\hline & from large companies & 96 & 33.8 \\
\hline & in age $18-25$ years & 78 & 27.5 \\
\hline & in age $26-35$ years & 80 & 28.2 \\
\hline & in age $36-45$ years & 54 & 19.0 \\
\hline & in age $46-55$ years & 54 & 19.0 \\
\hline & in age $56-65$ years & 16 & 5.6 \\
\hline
\end{tabular}

Source: authors' own survey data

Table 2 lists the answers related to the economic impact of the COVID-19 pandemic on the company that respondents work for (2021 survey examined the economic impact of the second wave of the pandemic). It goes without saying that the private sector plays a major role in promoting economic growth and standard of living of the population. Economic hardship of enterprises impacts the national economy and life of people. That is why the question is reasonable.

In the 2020 survey, $80.8 \%$ said that their company was affected by the pandemic compared to $78.2 \%$ respondents in 2021. In 2021, $16.2 \%$ of respondents reported their company not being impacted by the second wave of the pandemic as opposed to $12.6 \%$ of respondents in 2020. This slight increase in the share of respondents may indicate the adoption of measures by enterprises to improve their flexibility in the crisis situation. More input data would be, however, needed to draw definite conclusions. It also has to be noted that the 2020 respondents did not have a "moderately affected" answer option, thus no comparisons can be made. This answer option was added to the 2021 questionnaire after having carefully considered some feedback from the 2020 survey respondents. 2021 findings show that more than a fifth of respondents $(21.8 \%)$ viewed the situation in their company as critical. A quarter of respondents agree on an average impact of the COVID-19 pandemic on 
the company they work for and $31 \%$ of respondents say that their company is marginally affected.

Table 2. Answers to the question: To what extent do you think the company you work for was affected by the COVID-19 in economic terms?

\begin{tabular}{lcccccccccc}
\hline \multicolumn{1}{c}{} & \multicolumn{1}{c}{ answer options } \\
\hline applied filter & \multicolumn{1}{c}{$\begin{array}{c}\text { severely } \\
\text { affected }\end{array}$} & \multicolumn{2}{c}{$\begin{array}{c}\text { moderately } \\
\text { affected }\end{array}$} & \multicolumn{2}{c}{$\begin{array}{c}\text { marginally } \\
\text { affected }\end{array}$} & unaffected & \multicolumn{2}{c}{$\begin{array}{c}\text { I can't judge / } \\
\text { I don't want to } \\
\text { answer }\end{array}$} \\
\hline & 2020 & 2021 & 2020 & 2021 & 2020 & 2021 & 2020 & 2021 & 2020 & 2021 \\
\hline $\begin{array}{l}\text { Slovak } \\
\text { republic }\end{array}$ & 28.5 & 21.8 & - & 25.4 & 52.3 & 31 & 12.6 & 16.2 & 6.6 & 5.6 \\
\hline $\begin{array}{l}\text { small } \\
\text { companies }\end{array}$ & 28.8 & 36.7 & - & 16.3 & 50 & 30.6 & 17.3 & 12.2 & 3.8 & 4.1 \\
\hline $\begin{array}{l}\text { medium-sized } \\
\text { companies }\end{array}$ & 22.2 & 8.9 & - & 31.1 & 59.3 & 28.9 & 7.4 & 24.4 & 11.1 & 6.7 \\
\hline $\begin{array}{l}\text { large } \\
\text { companies }\end{array}$ & 35.6 & 18.8 & - & 29.2 & 46.7 & 33.3 & 13.3 & 12.5 & 4.4 & 6.3 \\
\hline women & 28.9 & 28.1 & - & 20.2 & 54.4 & 28.1 & 8.9 & 15.7 & 7.8 & 7.9 \\
\hline men & 27.9 & 11.3 & - & 34 & 49.2 & 35.8 & 18 & 17 & 4.9 & 1.9 \\
\hline
\end{tabular}

Source: authors' own survey data

A significant shift in the perception of the severity of the economic impact by gender was identified. In the 2020 survey, $8.9 \%$ of female respondents compared to $18 \%$ of male respondents said that the company they work for was not impacted. The latter research, however, shows roughly the same responses, namely $17 \%$ of male respondents (a slight drop) and as many as $15.7 \%$ of female respondents. The reasons for the negativity of female respondents in the 2020 survey can be their holding the hardest hit positions, spending more time taking care of children and the gender wage gap. It is not easy to give reasons for the marked shift in the 2021 survey outcomes. It is assumed that time played a role here. The months of summer with eased restrictions were followed by drastic measures imposed by the government with regard to the second wave of the COVID-19 pandemic. This can be a reason for female respondents' perception of the situation in their workplaces. Even though the months of January and February were also critical, the situation was easier in the sense that workers found ways of coping with the crisis. This is believed to be a reason for the female respondents to give more positive answers. It should be noted, however, that the assessment of the motives of a person's perception will always be associated with a degree of uncertainty. 


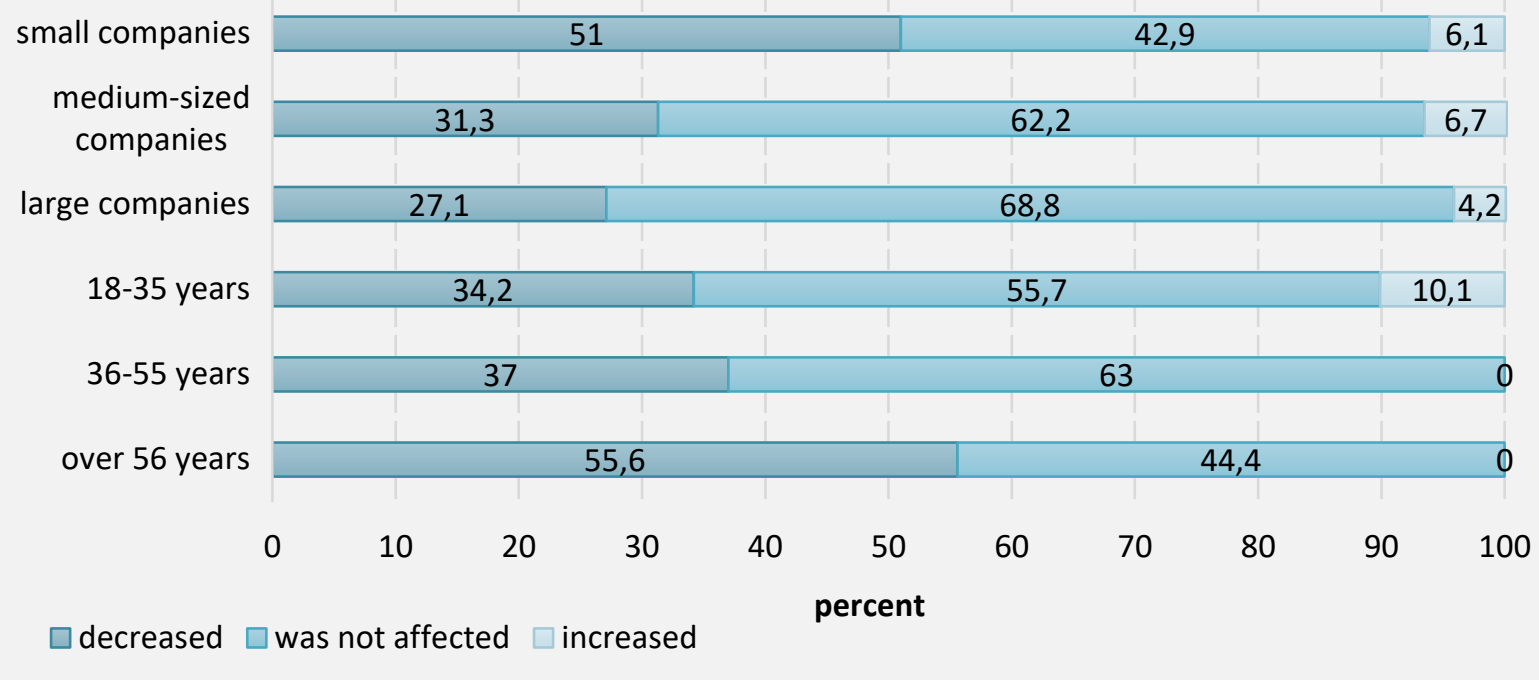

Figure 1. What impact did the second wave of the COVID-19 pandemic have on your income?

Source: authors' own survey data

Figure 1 provides the data on the impact of the pandemic on the respondents' income by age and company size (survey of January and February 2021). Significant differences in survey outcomes were associated with company size. In the 2020 survey, the answers from respondents working in small and medium-sized enterprises were almost identical. Concerning the respondents working for large enterprises, the share of respondents was only approximately 8 percentage points higher. The 2021 survey shows different answers by respondents. In the category of small enterprises, the option of decreased income was chosen by $50 \%$ and $51 \%$ of respondents in 2020 and 2021 survey respectively. In the case of medium-sized enterprises, the situation improved noticeably. Lower income was reported by $50 \%$ of respondents in the first wave of the pandemic compared to $31.3 \%$ of respondents in the second one. In large enterprises, $42.2 \%$ of respondents claimed to have a lower income in the 2020 survey in contrast to $27.1 \%$ of respondents in the 2021 survey. It follows that the impact of the second wave of the pandemic on employee income varies by company size (51\% of respondents report income decrease in small businesses vs. $27.1 \%$ in large enterprises|. An increased income was reported by $1.3 \%$ and $5.6 \%$ of respondents in the first and second survey respectively. In the age category 18 to 35 years, $2.3 \%$ of respondents reported an income increase in 2020 compared $10 \%$ of respondents in 2021 . The income of older respondents did not increase in either wave of the COVID-19 pandemic. In the age category 18 to 35 years, the number of respondents reporting a decreased income dropped (44.2\% of respondents in 2020 vs. $34.2 \%$ of respondents in 2021). In the age group 36 to 55 years, 55.6\% of respondents reported a decrease in their income in the 2020 versus $37 \%$ of respondents in the 2021 survey. The differences in data are not statistically insignificant. Workers 55 and older experienced a decrease in their income most, 55.6\% of respondents in the second wave of the pandemic and $36.4 \%$ in the first one. The survey results confirm that the enterprise size determines, to a certain extent, its resilience to the impacts of the crisis. It was established that larger enterprises do less modify their employee compensation. Moreover, it was found that the risk of salary decrease is higher for employees in the age group 55 and older. 


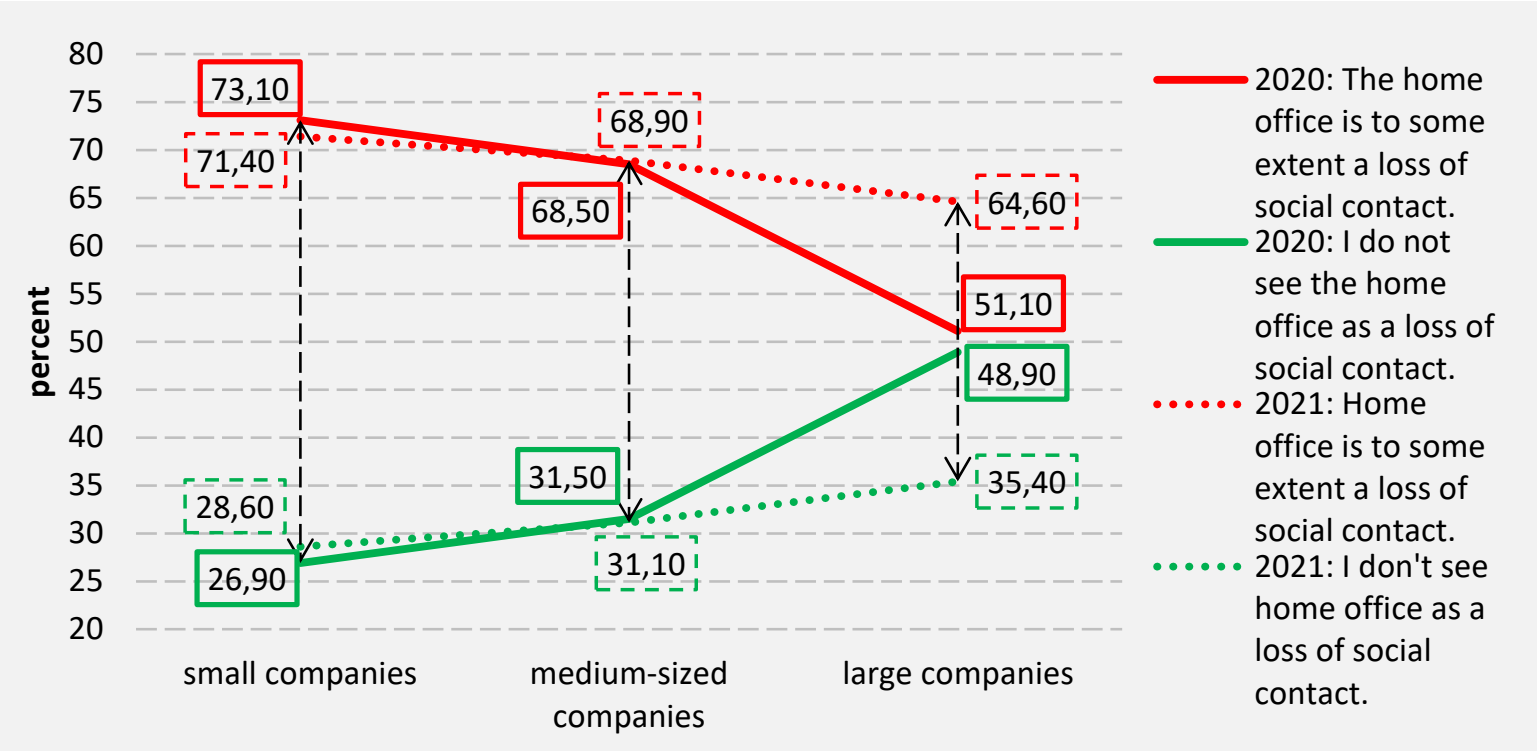

Figure 2. Which statements are true for you?

Source: authors' own survey data

In addition to the impact of the pandemic on organisations and employee income, distant working in the light of social interaction was examined. Figure 2 illustrates respondent statements on distant working and social interaction. In the 2020 survey, $48.9 \%$ of respondents working in large companies said they did not consider working from home as a loss of social contact - which was dramatically more than in the case of small companies, where only $26.9 \%$ of respondents expressed the same opinion. The findings were in sharp contrast with the answers by the respondents working in small enterprises. The difference in answers can be attributed to formal relationships in large companies in contrast to close relationships in small ones. It seems, though, that the social isolation of 4 months had made the differences smaller. The second survey data showed that only $35.4 \%$ of respondents in large companies no longer consider a home office to be a loss of social contact (a 13.5 p.p. decrease). The reason can be the growing employee frustration in large enterprises. During the first wave, the employees were deprived of social interactions. In the summer months, however, the restrictive measures were eased. During the second wave, a vast range of strict containment measures were adopted. The measures were mainly intended to curtail human interaction in and out of work. This could be why the employees working for large enterprises began to feel lonely while working from home. Regarding small and medium-sized enterprises, there was no change in respondent answers. No one has anticipated a pandemic like this one to break out. The employers were forced to ask their employees to work at home and not at their premises.

Before the pandemic, work from home was not a popular choice in Slovakia. Organizations only seldom allowed their employees to work from home. Benelux countries, Denmark, France, Finland and Sweden, on the other hand, all have had a long history of working from home. Hunter (2019), among others, maintains that working from home encourages employees to work more efficiently and achieve higher productivity. It goes without saying that good working conditions must be provided, including information and communication tools. The next question dealt with employee productivity while working from home. The data are shown in Figure 3. 


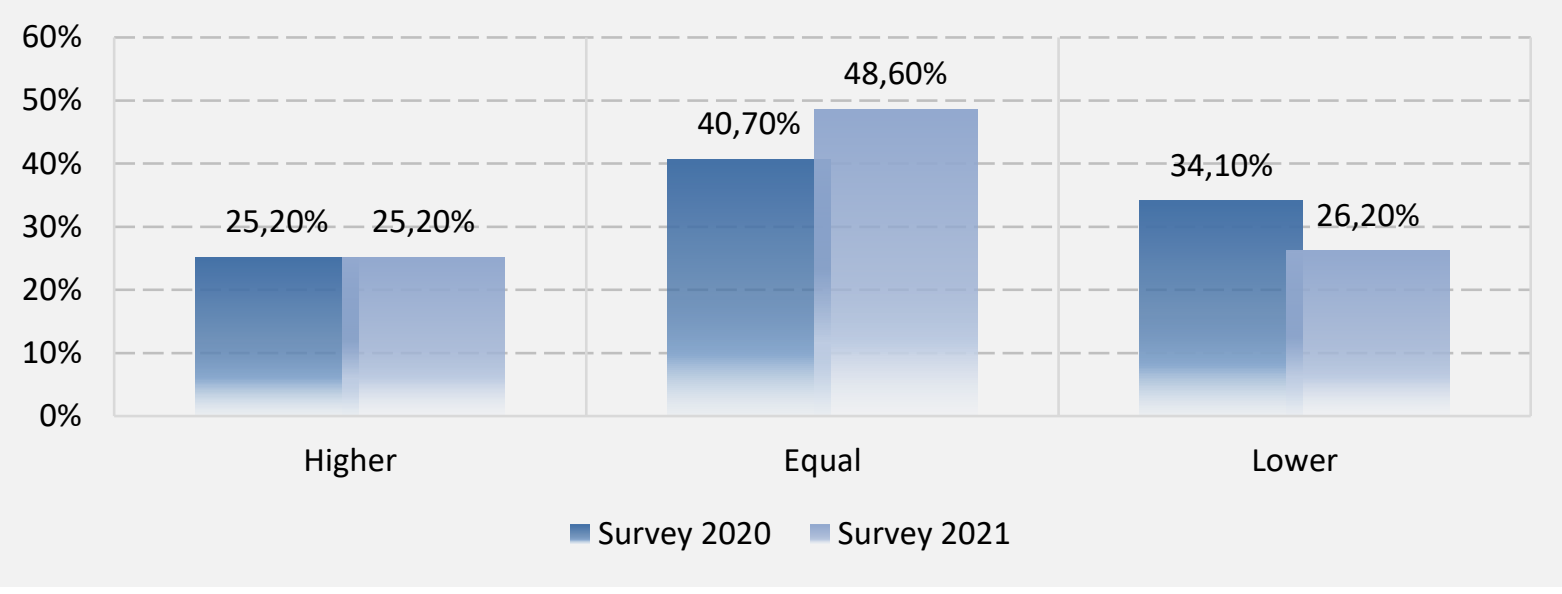

Figure 3. Work productivity while working at home

Source: authors' own survey data

It can be seen in Figure 3 that $25.2 \%$ of respondents in both surveys said their productivity was higher when working remotely. $34.1 \%$ of respondents claimed having lower productivity when working remotely in the 2020 survey versus $26.2 \%$ of respondents in the 2021 survey. In the 2021 survey, $48.6 \%$ of respondents said they are as productive in their home offices as in their workplaces (an increase by 7.9 p.p. compared to the 2020 survey). Next, $25.20 \%$ of respondents said they were more productive when working from home, and there were also some shifts of respondents from lower to equal productivity. If the trend goes beyond the pandemic, working from home can become the norm for most businesses as it is appealing to both employees and employers. Managers and those in leadership positions, however, have to find ways to promote high levels of performance.

Digital technologies are more and more becoming a part of everyday life. In order to work from home effectively, digital technologies and tools are a must. Recently, the Slovak labour market has faced the issue of workforce not having even the basic ICT skills. According to the Index of Digital Economy and Society, sub-indicator Human Capital, Slovakia is below the EU average (European Commission, Digital economy and Society Index 2020). Table 3 below provides the data on DESI, sub-index Human Capital for Slovakia and the EU 2020.

Table 3. Human capital indicators in DESI

\begin{tabular}{lcc}
\hline & DESI Slovakia 2020 & DESI EU 2020 \\
\hline $\begin{array}{l}\text { At least basic digital skills } \\
\% \text { individuals }\end{array}$ & $54 \%$ & $58 \%$ \\
\hline $\begin{array}{l}\text { Above basic digital skills } \\
\% \text { individuals }\end{array}$ & $27 \%$ & $33 \%$ \\
\hline $\begin{array}{l}\text { At least basic software skills } \\
\% \text { individuals }\end{array}$ & $56 \%$ & $61 \%$ \\
\hline $\begin{array}{l}\text { ICT specialist } \\
\% \text { total employment }\end{array}$ & $3.20 \%$ & $3.90 \%$ \\
\hline $\begin{array}{l}\text { Female ICT specialist } \\
\% \text { female employment }\end{array}$ & $0.90 \%$ & $1.40 \%$ \\
\hline $\begin{array}{l}\text { ICT graduates } \\
\% \text { graduates }\end{array}$ & $3.30 \%$ & $3.60 \%$ \\
\hline
\end{tabular}

Source: DESI 2020, European Commission 
As mentioned before, the outbreak of the pandemic in March 2020 made companies to switch their employees from working from office to working from home. For some employees, the situation was a new one. In order to be able to work remotely, employees had to use information and communication technologies. Concerning the above DESI, sub-index Human Capital, some employees faced a situation of not having adequate skills to use information and communication technologies. Figure 4 shows the 2020 survey findings on employee ICT skills.

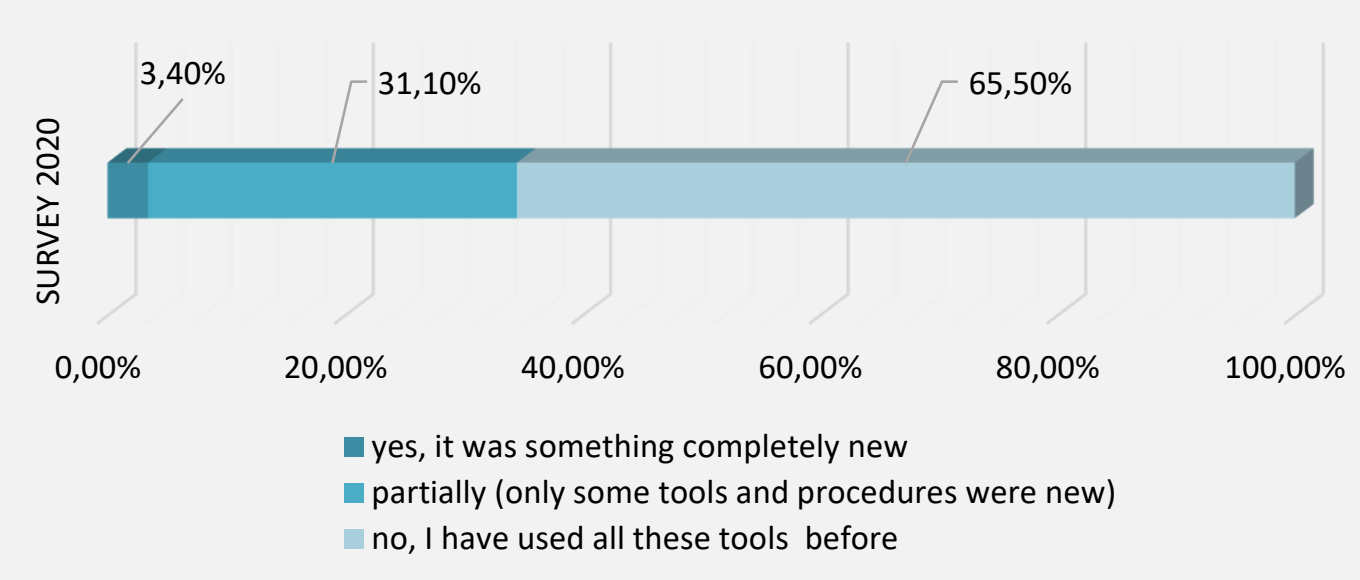

Figure 4. Required training to use online software, tools, platforms, network connections or systems

Source: authors' own survey data

$65.5 \%$ of respondents said they did not need any additional training on using ICT, such as online software, tools, platforms, network connections or systems. An important finding was, however, that $31.1 \%$ of respondents needed to learn some new procedures. $3.4 \%$ of respondents said that working from home and using ICT were unknown to them. The survey data show that more than one third of respondents (34.5\%) did not have adequate skills for a smooth transition to remote work. Some adaptation is needed to acquire new skills and apply them effectively in practice. It needs time to learn and practice new skills. The survey of 2021 also attempted to find whether working from home improved ICT skills of respondents. The findings are given in Figure 5.

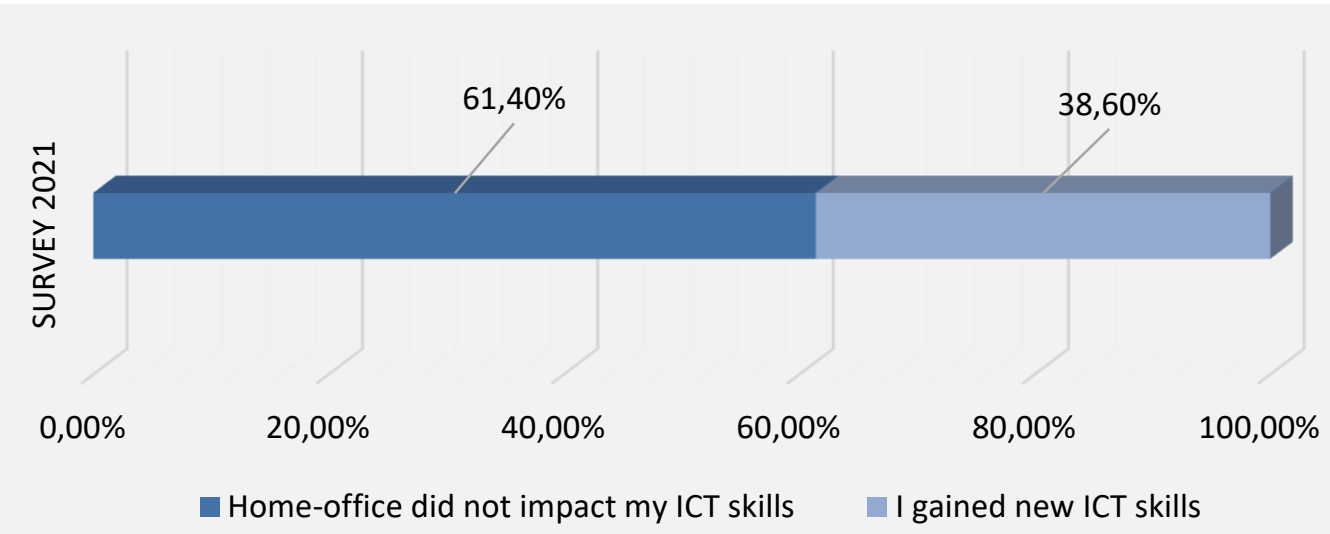

Figure 5. The impact of home-office on ICT skills

Source: authors' own survey data 
In both surveys, the majority of computer literate respondents $(61.4 \%)$ said home office had no impact on their ICT skills. It can be assumed that some respondents worked from home before the outbreak of the pandemic and some used the same tools, software, and online platforms which they used when working from office. The other group $(38.6 \%)$ of respondents were those who learned new skills while working from home. The 2020 survey found that $34.5 \%$ of respondents needed additional ICT training. In the 2021 survey, $38.60 \%$ of respondents stated they acquired new ICT skills (the deviation of 4.1\%).

Working from home brought a set of new challenges for employers. They were associated with the organization of work, hours of work, effective performance management and the like. One of the biggest challenges was the quick implementation of ICT. In practice, it turned out that many employers were not well prepared for this process; they had no IT experts available who could technically ensure a smooth transition from work from the office to work from home. Moreover, not all their employees had adequate skills to be able to work from home. This is the reason why employers had to hire IT experts. Recently, there have been many job openings for IT experts in Slovakia. In spite of unfavourable economic situation and rising unemployment, there have been a growing number of e-businesses. They specialize mainly in the buying and selling of goods and services over an electronic network. The following figure shows the number of workers in Information and Communication sector according to statistical classification of economic activities SK NACE Rev.2. (from Q3 2019 to Q3 2020).

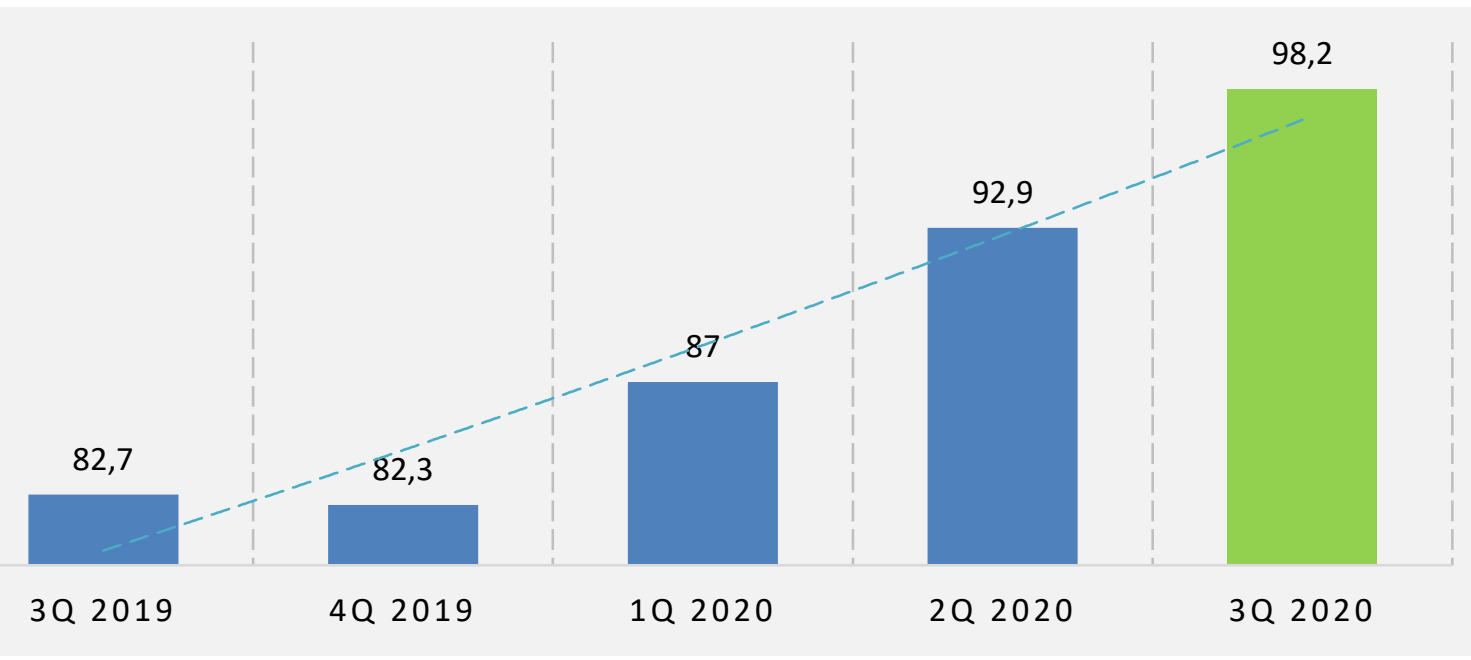

Figure 6. Workers in Information and communication sector according to statistical classification of economic activities SK NACE Rev.2 (in thousands)

Source: Statistical Office of Slovak Republic

\section{Conclusion}

The COVID-19 pandemic has hit hard all the processes and activities worldwide. The processes and activities must be modified so that societies remain functional. In this relation, the labour market is also a dynamic entity featuring an array of complex and simultaneous processes and relations among all its players. Therefore, it is necessary to perceive the current crisis as one of the key factors determining the multilateral nature of the labour market.

The COVID-19 pandemic has had negative effects on the economic growth in Slovakia. As the survey data indicate, the pandemic has brought a rising unemployment rate and drops in income from work for certain groups of people. Unemployment has been rising in all sectors, except for the ICT sector. In the Q3 of 2020, the number of people in ITC jobs 
increased by 15.5 thousand, which is an increase of as much as $18.7 \%$. The rising trend is recorded in all three 2020 quarters. Employment in the ICT sector has been rising for several reasons, such as the introduction of remote working, so employers needed to hire ICT specialists, or the growth of e-commerce which is dependent on ICT. Many businesses had to suspend their business activities and search for new ways of doing business due to lock down restrictions. The shift to e-commerce has been the right solution.

In connection with the recent changes in the labour market, a number of questions have arisen which cannot be answered at this point. What we know for sure is that many jobs will disappear in the fields we would not expect to, e. g. accountants or administrative assistants. There is a clearly visible trend in tourist industry, in which the personalised final products along with the implementation of applications and digitization have sharply cut the number of clerks and increased the number of customers. Creation of new jobs, both in quantitative and especially qualitative terms, cannot, however, be predicted. A matter of importance is chiefly the knowledge and skills needed for the future jobs. Since employees seek flexible arrangements, it will be necessary to adopt several legislative changes in the Slovak employment law. In Slovakia, even those employers believing in established and traditional ways of working began to favour working from home. As a matter of fact, remote working allows reducing employees' work-related costs while not decreasing their work performance. Employees, however, are keen to go back to the office for a lack of social interaction and frustration. During the first wave Covid-19 of the pandemic only half of the respondents from large companies mentioned this negatives, during the second wave in every size category of the companies in more than $64 \%$ cases employees perceived the home office as a loss of a social contact. A pressing issue is that of what education and training students should acquire prior to entering the labour market. It also has to be identified what knowledge and skills will be required in the labour market in light of extensive use of technology, ICT in particular.

The COVID-19 pandemic has affected all aspects of our lives. While discussing the negative effects of the pandemic, some positive aspects should not go unnoticed. The research findings show that the pandemic has triggered and accelerated the implementation of the Industry 4.0 in Slovak businesses. The use of ICT has become more frequent and powerful, thus giving opportunities for structural changes in economy, labour market and future economic growth.

\section{Acknowledgement}

This paper was supported by the Slovak Ministry of Education's Scientific grant agency VEGA: "Assessment changes in the qualitative structure of international economic relations under the influence of Industry 4.0 with implications for the EU and Slovak economic policies". Project registration number: [Reg. No.: 1/0462/20]. 


\section{References}

Allen, T. D., Golden, T. D., \& Shockley, K. M. (2015). How effective is telecommuting? Assessing the status of our scientific findings. Psychol. Sci. Public Interest, 16(2), 40 68. doi: https://doi.org/10.1177/1529100615593273.

Baruch, Y., \& Nicholson, N. (1997). Home, Sweet Work: Requirements for Effective Home Working, Journal of General Management, 23(2), 15-30. doi: https://doi.org/10.1177/030630709702300202.

Belás, J., Amoah, J., Petráková, Z., Kliuchnikava, Y., \& Bilan, Y. (2020). Selected Factors of SMEs Management in the Service Sector. Journal of Tourism and Services, 11(21), 129-146. doi:10.29036/jots.v11i21.215.

Belás, J., Gavourova, B., Kubalek, J., \& Kubak, M. (2020). Discrepancies in perception and evaluation of macroenvironment - sectoral analysis. Journal of Business Economics and Management, 21(4), 1072-1092. doi: https://doi.org/10.3846/jbem.2020.12274.

Bilan, Y., Mishcuk, H., Samoliuk, N., \& Grishnova, O. (2019). ICT and economic growth: Links and possibilities of engaging. Intellectual Economics, Vol. 13(1), 93-104. doi: https://doi.org/10.13165/IE-19-13-1-07.

Contreras, F., Bykal, E., \& Abid, G. (2020). E-Leadership and Teleworking in Times of COVID-19 and Beyond: What We Know and Where Do We Go. Frontiers in Psychology, 11, 1-11. doi: 10.3389/fpsyg.2020.590271.

Davidescu, A.A., Apostu, S., Paul, A., \& Casuneanu, I. (2020). Work flexibility, job satisfaction, and job performance among romanian employees-implications for sustainable human resource management. Sustainability, 12(15), 1-53. doi: https://doi.org/10.3390/su12156086.

Dobrosotskiy, V. I., Semenova, G. N., Kazarinova, E. B., \& Falina, N. V. (2019). Venture investments into digital education in the conditions of industry 4.0: Problems of attraction and directions of usage. On the Horizon, 27(3-4), 213-218. doi: https://doi.org/10.1108/OTH-07-2019-0035.

European commision (2020). Digital Economy and Society Index (DESI) 2020 Human capital, Retrieved February 10, 2021 from https://ec.europa.eu/digital-singlemarket/en/human-capital-and-digital-skills.

Formánek, I., \& Krajčík, V. (2017). Identification of creative and innovative companies. Creativity studies, 10(2), 111-121. doi: 10.3846/23450479.2017.1344735.

Hunter, P. (2019). Remote working in research, An increasing usage of flexible work arrangements can improve productivity and creativity. EMBO reports, 20(1), 1-4. doi: https://doi.org/10.15252/embr.201847435.

Kniffin, K. M., et. al. (2020). COVID-19 and the Workplace: Implications, Issues, and Insights for Future Research and Action. American Psychologist, 76(1), 63-77. doi:http://dx.doi.org/10.1037/amp0000716.

Krajňáková, E., \& Vojtovič, S. (2017). Struggles of older workers at the labour market. Economics and Sociology, 10(1), 319-333. doi: 10.14254/2071789X.2017/10-1/23.

Lampropoulos, G., Siakas, K., Anastasiadis, T. (2019). Internet of things in the context of Industry 4.0: An overview. International Journal of Entrepreneurial Knowledge, 7(1), 4-19. doi:10.2478/ijek-2019-0001.

Leduc, S., \& Liu, Z. (2020). The Uncertainty Channel of the Coronavirus. FRBSF Economic Letter, Federal Reserve Bank of San Francisco, Retrieved February 8, 2021 from https://www.frbsf.org/economic-research/files/el2020-07.pdf. 
Mallett, O., Marks, A., Skountridaki, L. (2020). Where does work belong anymore? The-implications of intensive homebased working. Gender in Management, 35 (7/8), 657-665. doi: 10.1108/GM-06-2020-0173.

Matijová, M., Onuferová, E., Rigelský, E., \& Stanko, V. (2019). Impact of Selected Indicators of Tourism Capacity and Performance in the Context of the Unemployment Rate in Slovakia. Journal of Tourism and Services, 10(19),1-23. doi: 10.29036/jots.v10i19.95.

Min, X., Jeanne, M. D., \& Suk, H. K. (2018). The Fourth Industrial Revolution: Opportunities and Challenges. International Journal of Financial Research, 9(2), 90-95. doi:10.5430/ijfr.v9n2p90.

Morgan, A. K., Awafo, B. A., \& Quartey, T. (2021). The effects of COVID-19 on global economic output and sustainability: evidence from around the world and lessons for redress. Sustainability: Science, Practice and Policy, 17(1), 77-81. doi: 10.1080/15487733.2020.1860345.

Mura, L. (2020). Innovations and marketing management of family businesses: results of empirical study. International Journal of Entrepreneurial Knowledge, 8(2), 56-66. doi:10.37335/ijek.v8i2.118.

Müller, J., \& Kiel, D. (2018). What drives the implementation of industry 4.0? The role of opportunities and challenges in the context of sustainability. Sustainability, 10(1), 124. doi: https://doi.org/10.3390/su10010247.

Saadat, S., Rawtani, D., \& Hussain, C. M. (2020). Environmental Perspective of COVID-19. Science of the Total Environment, 728(138870), 1-6. doi: 10.1016/j.scitotenv.2020.138870.

Statistical office of Slovak republic. (2021). Thousand of workers in Information and communication sector according to statistical classification of economic activities SK $\begin{array}{lllll}\text { NACE Rev.2. Retrieved } & \text { February } & 12, & & \text { from }\end{array}$ http://datacube.statistics.sk/\#!/lang/en.

Toscano, F., \& Zappalà, S. (2020). Social isolation and stress as predictors of productivity perception and remote work satisfaction during the COVID-19 pandemic: The role of concern about the virus in a moderated double mediation. Sustainability, 12(23), 114. doi: https://doi.org/10.3390/su12239804.

Ustaev, R. M., Parakhina, V. N., Patrick, E., \& Novikova, E. N. (2018). Human capital in digital economy: Modern trends and innovative development opportunitie. CIEDR 2018 The International Scientific and Practical Conference Contemporary Issues of Economic Development of Russia: Challenges and Opportunities, 793-802. doi: 10.15405/epsbs.2019.04.86.

Wang, B., Liu, Y., Qian, J., \& Parker, S. K. (2021). achieving effective remote working during the COVID-19 pandemic: A work design perspective. Applied Psychology, 70(1), 16-59. doi: https://doi.org/10.1111/apps.12290.

Zhang, J. (2021). People's responses to the COVID-19 pandemic during its early stages and factors affecting those response. Humanities and Social Sciences Communications, 8(1), 1-13. doi: https://doi.org/10.1057/s41599-021-00720-1. 